\title{
The Influence Aggregates Artificial to the Strength Concrete
}

\author{
Andi Yusra $^{1}$, Inseun Yuri Salena ${ }^{2}$, Heri Safrizal ${ }^{3}$ \\ ${ }^{1}$ Civil Engineering Department, Teuku Umar University, Alue Peunyareng, Meulaboh, Indonesia \\ ${ }^{2}$ Civil Engineering Department, Teuku Umar University, Alue Peunyareng, Meulaboh, Indonesia \\ ${ }^{3}$ Civil Engineering Department, Teuku Umar University, Alue Peunyareng, Meulaboh, Indonesia \\ yusra.andi@yahoo.com
}

\begin{abstract}
This study was conducted to investigate the effect of using aggregates artificial that is clay soil as partial substitution for coarse aggregates in concrete by determine the mass of concrete and its effect on the compressive strength. The proportion of aggregate artificial in design mix is $0 \%, 10 \%, 20 \%$, and $30 \%$ with $w / c$ ratio 0.3 and $25 \mathrm{MPa}$ in strength design. The study used cylinder sample at test age 28 and 56 days. The weight of aggregates artificial is $12.97 \mathrm{~kg}$ and $13.05 \mathrm{~kg}$ for $0 \%$ subtitution, $12.07 \mathrm{~kg}$ and $12.12 \mathrm{~kg}, 10 \%$ subtitution, $11.45 \mathrm{~kg}$ and $11.58 \mathrm{~kg}(20 \%)$ and $10.95 \mathrm{~kg}$ and $11.17 \mathrm{~kg}, 30 \%$ subtitution. The test result in $0 \%$ used aggregates artificial obtained strength concrete is 25.67 MPa and 25.95 MPa, 23.40 MPa and 23.87 MPa (10\% used aggregates artificial), 18.02 MPa and $18.49 \mathrm{MPa}(20 \%$ used) and $15.29 \mathrm{MPa}$ and $15.85 \mathrm{MPa}$ (30\% used aggregates artificial). The results indicated that the higher the percentage in ALWA, the less the weight of concrete. Variation in aggregates artificial percentages affected the compressive strength, but in concrete ages, it did not have effect. However, the strength of the concrete may decrease, but still can be used as a structural concrete with a lighter weight of concrete.
\end{abstract}

Keywords: aggregates artificia; clay soil; strength concrete

\section{Introduction}

Aceh Province is one of the areas that have a high level of earthquake intensity. The magnitude of the intensity of the earthquake caused many casualties and destroyed many resident building. Generally construction planning and implementation in residential buildings, educational institutions, commercial, industrial and other public facilities are dominated by concrete structures that use aggregate materials as one of the main components.

These Aggregates make the mass of concrete increased and heavier. Another way to get lighter concrete is to replace some of the coarse aggregates with lightweight aggregates using alternative materials that are easily found in the environment. The lightweight aggregates can reduce the unit weight of concrete, but has compressive strength that is almost the same as normal concrete.

One way to get lighter concrete is to replace some of the coarse aggregates on the concrete. This coarse aggregate will be partially substituted with artificial aggregates made from clay soils. The number of small industries engaged in the manufacture of bricks in Nagan Raya, especially Gampong Ujung Fatihah has a type of clay soil that can be utilized as a material of lightweight aggregates.

This coarse aggregate of aggregates artificial is made from soil clay by adding rice husk ash in it. The addition of rice husk ash is to increase the strength because the silica content in it is high. The use of rice husk ash is to reduce the rice husk waste that accumulates at the location of rice mill. Also rice husk ash and clay soil easily found in the surrounding Regency of West Aceh.

\section{Research Method}

\subsection{Preparation of Samples}

Production of aggregates artificial is completed in brick factory in Nagan Raya Districts. Concrete work started from examination of aggregate physical properties, making of specimens, curing and testing of specimens were conducted at the Public Works Laboratory of West Aceh. 
The material used to produce artificial of aggregate is Portland cement, clay soil, rice husk ash, fine aggregate (sand) and water. Then, as comparison, normal concrete was made at $25 \mathrm{MPa}$ concrete strength with Portland cement material, fine aggregate (sand), coarse aggregate (gravel) and water. Portland cement type I used as ingredients in producing concrete. There is no Laboratory examination for cement because it meets (Tjokrodimuljo, 2007). The examination is only done visually against the torn bag and there are no hard clumps on the cement.

Examination of coarse aggregates (gravel) and fine aggregates (sand) as concrete-forming materials is necessary to obtain good material quality (Tjokrodimuljo, 2007). This examination is performed on aggregate properties that include specific gravity, absorption, bulk density, sieve analysis, and fineness modulus. Then continue with artificial aggregate production process which is done in brick making factory in Nagan Raya Districts.

The water used in the mixture of concrete and its curing comes from clean water obtained from the West Aceh Public Works Laboratory. The water in this laboratory meets the standard of clean water suitable for concrete mix.

\subsection{Methods}

a. Process and Producing Aggregates Artificial

According to (SNI 03-2461-2002), aggregates artificial made by heating materials, such as furnace slag, smelting iron diatomaceous clay, fly ash, ground flakes, slate and clay. One of the artificial light aggregates is made of clay that through process burning with temperature between $500-1250^{\circ} \mathrm{C}$ and can be used for lightweight structural concrete with specific gravity with ranges from $1400-2000 \mathrm{~kg} / \mathrm{m}^{3}$.

The clay should fulfill the requirements such as, containing alumina silicates and dissociated substances which may produce gases above its melting temperature. Because the weight is very light then the concrete produced will be lighter than normal concrete. The gradation of aggregates requirements for lightweight concrete using aggregates artificial following (STM C330-89, 2002) standard (Standard Specification Aggregate for Structural Concrete) can be seen in Table 1 below:

Table 1. Gradation of Aggregates Artifcial ASTM C330-89

\begin{tabular}{|l|l|}
\hline Sieve Size Range $(\mathrm{mm})$ & Passing Percentage (\%) \\
\hline 50 & 100 \\
\hline 38 & 100 \\
\hline 25 & 100 \\
\hline 19 & $90-100$ \\
\hline 12.50 & - \\
\hline 9.50 & $10-50$ \\
\hline 4.75 & $0-15$ \\
\hline 2.38 & - \\
\hline
\end{tabular}

The basic ingredients of artificial aggregate are clay soils. Clay used as aggregate is first destroyed and mixed with rice husk ash about $15 \%$ from the weight of clay soils. Then clay formed in to granular shape with grain size $+16 \mathrm{~mm}$ and burned with temperature between 500 - $1250{ }^{0} \mathrm{C}$. After burning for several hours, then the aggregates artificial is cooled at room temperature. The aggregate artificial then soaked in to the water for 24 hours, in order for the aggregate to be in saturated surface dry condition. After soaking, aggregate artificial is ready to be used as light aggregate in concrete. 


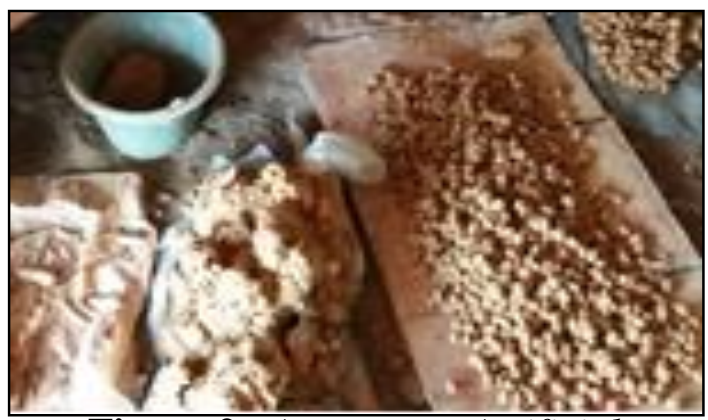

Figure 2. Aggregates Artificial

\section{b. Testing of physic Properties of Aggregates}

Aggregates used in concrete mixtures can be either natural aggregates or artificial aggregates. Sand and gravel are natural while artificial aggregates are derived from processed products first such as the result of blast furnace slag, fraction tile, concrete waste, fly ash, clay soil and so on. Examination of aggregate physical properties includes examination:

- Specific gravity

- Absorption

- Bulk Density

- Sieve analysis

\section{c. Mixture Proportions}

Mix design of normal concrete and aggregate artificial planned using (Tjokrodimuljo, 2007) with concrete strength design is $25 \mathrm{MPa}$.

\section{d. Concrete Mixture Work}

Normal concrete work begins with mixing of concrete-forming materials (sand, gravel, cement and water). Then the material is placed into concrete mixer. Slump test measurement for fresh concrete is carried out. The mix was then placed into the mold for 24 hours.

In aggregate artificial substitution concrete processes, materials such as sand, gravel, aggregate ALWA and cement are mixed first according to their own percentages. Then the material is placed into concrete mixer and water added. Slump test measurement for fresh concrete is carried out. The mix was then placed into the mold for 24 hours..

After 24 hours, the concrete were taken out from every mold and then they were submerged in the water tank in the Laboratory of Public Works of West Aceh. Testing of compressive strength is carrier out after the concrete reaches the age of 28 and 56 days. Concrete is loaded vertically or parallel to the cylinder slowly until the test object is destroyed. The total number of test specimens is 24 cylindrical pieces $(\varnothing 15 \mathrm{~cm}, T=30 \mathrm{~cm})$ with various percentage of aggregate, showed in Table 2.

Table 2. The number of concrete specimen

\begin{tabular}{|c|c|c|c|c|c||}
\hline \multirow{2}{*}{$\begin{array}{c}\text { Age of } \\
\text { Compressive } \\
\text { Strength Test }\end{array}$} & \multicolumn{4}{|c|}{ Percentage of ALWA } & \multirow{2}{*}{$\begin{array}{c}\text { Total of } \\
\text { Specimen }\end{array}$} \\
\cline { 2 - 6 } & $0 \%$ & $10 \%$ & $20 \%$ & $30 \%$ & \\
\hline 28 Days & 3 & 3 & 3 & 3 & 12 \\
\hline 56 Days & 3 & 3 & 3 & 3 & 12 \\
\hline & 6 & 6 & 6 & 6 & 24 \\
\hline
\end{tabular}




\section{Discussion}

\subsection{Results}

This section presents the results analysis from the examination of aggregate physical properties, the design of the proportion of concrete mixtures and the test results of compressive strength. The description of the results of the analysis is presented in the form of tables and graphs, in order to be easy to understand.

a. Physical Properties of Aggregates

The results of examination of aggregate physical properties indicate that the aggregate used qualifies as concrete forming material.

- Bulk Density

The result of average of bulk density calculated for each type of aggregate is shown in Table 3.

Table 3. Bulk Density of Aggregates

\begin{tabular}{|c|c|c|c|c|}
\hline \multirow{2}{*}{ No. } & \multirow{2}{*}{ Type of Aggregates } & Volume Weight & \multicolumn{2}{|c|}{ References } \\
\cline { 3 - 5 } & & $(\mathrm{kg} / \mathrm{l})$ & Orchard & ASTM \\
\hline 1 & Coarse Aggregates & 1.828 & - & $1.6-1.9$ \\
\hline 2 & Fine Sand & 1.679 & $>1.445$ & - \\
\hline
\end{tabular}

The fine aggregate used in this study can be used as a concrete-forming material with a volume weight of $1.679 \mathrm{~kg} / \mathrm{L}$. As suggested by [4], he thinks that the weight of a good aggregate volume is greater than $1,445 \mathrm{Kg} / \mathrm{L}$. According to [1] the weight of the aggregate volume also meets the specification of $1,828 \mathrm{~kg} / \mathrm{L}$, ranging from $1.6-1.9 \mathrm{~kg} / \mathrm{L}$.

- Specific gravity and absorption

Table 4. Specific Gravity

\begin{tabular}{|c|c|c|c|c|c|}
\hline \multirow{2}{*}{ No. } & \multirow{2}{*}{ Type of Aggregates } & \multicolumn{2}{|c|}{ Specific Gravity } & \multicolumn{2}{c|}{ References } \\
\cline { 3 - 5 } & & SG (SSD) & SD (OD) & Troxell & ASTM \\
\hline 1 & Coarse Aggregates & 2.65 & 2.60 & - & $1.6-$ \\
\hline 2 & Fine Sand & 2.43 & 2.36 & $2-2.6$ & 3.20 \\
\hline
\end{tabular}

The results of the calculation of specific gravity and absorption obtained for each type of aggregate are presented in the following Table 4 and 5.

Table 5. Absorption

\begin{tabular}{|c|c|c|c|c|}
\hline \multirow[b]{2}{*}{ No } & \multirow[b]{2}{*}{ Types of Aggregate } & \multirow[b]{2}{*}{ Absorbtion \% } & \multicolumn{2}{|c|}{ References } \\
\hline & & & $\begin{array}{c}\text { Orchard } \\
(1979)\end{array}$ & ASTM \\
\hline 1 & Coarse Aggregate & 1.987 & \multirow{2}{*}{$0.4-1.9$} & $0,2-4,0$ \\
\hline 2 & Fine Sand & 3.148 & & - \\
\hline
\end{tabular}

From Table 4 it can be seen that the specific gravity of the Saturated Surface Dry aggregates (SSD) used comply with the requirements indicated by (ASTM C.33-02, 2002), for gravel $2.65 \mathrm{~kg} / \mathrm{L}$ and $2.60 \mathrm{~kg} / \mathrm{L}$ dry aggregate weight (OD), for the specific gravity of the Saturated Surface Dry aggregates (SSD saturated sand aggregate (SSD) is $2.43 \mathrm{~kg} / \mathrm{L}$ and 2.36 
$\mathrm{kg} / \mathrm{L}$ dry sand aggregate (OD). this aggregate has also met the requirements specified by [7] ranging from $2.0 \mathrm{~kg} / \mathrm{L}-2.6 \mathrm{~kg} / \mathrm{L}$ and [1] $1.6 \mathrm{~kg} / \mathrm{L}-3.20 \mathrm{~kg} / \mathrm{L}$.

Furthermore, in table 5 it can be seen that the coarse aggregate absorption value obtained is 1.987. Absorption of coarse aggregate is still in accordance with absorbency value determined by ASTM that is $0.2-4.0$. While for fine aggregate absorption is 3,148. Fine aggregate absorption did not match (Orchard, 1979) determined $0.4 \%-1.9 \%$ and (ASTM C.33$02,2002) 0.2 \%-2.0 \%$.

- Gradation of Aggregates

Table 6. Fineness Modulus (FM)

\begin{tabular}{|c|c|c|c|}
\hline \multirow{2}{*}{ No } & Types of Aggregate & Fineness & References \\
\cline { 4 - 4 } & Modulus (FM) & ASTM \\
\hline 1 & Coarse Aggregate & 6.28 & $5.5-8.0$ \\
\hline 2 & Fine Sand & 2.33 & $2.2-2.6$ \\
\hline 3 & Agregat campuran & 5.09 & $4.0-7.0$ \\
\hline
\end{tabular}

b. Casting of Concrete Specimens

The following table shows the proportion of mixture for $1 \mathrm{~m} 3$ of concrete.

Table 7. Mix Proportions

\begin{tabular}{|c|c|c|c|c|c|c|}
\hline \hline \multirow{2}{*}{$\begin{array}{c}\text { W/C } \\
\text { Ratio }\end{array}$} & \multirow{2}{*}{$\begin{array}{c}\text { Aggregates } \\
\text { Percentage }\end{array}$} & \multicolumn{5}{|c|}{ Material $(\mathrm{Kg})$} \\
\cline { 3 - 7 } & & Water & Cement & $\begin{array}{c}\text { Coarse } \\
\text { Aggregates }\end{array}$ & $\begin{array}{c}\text { Fine } \\
\text { Aggregate }\end{array}$ & ALWA \\
\hline \hline \multirow{4}{*}{0.518} & $0 \%$ & 186.760 & 360.82 & 1362.74 & 527.94 & 0 \\
\cline { 2 - 7 } & $10 \%$ & 186.998 & 361.00 & 1041.46 & 468.39 & 167.76 \\
\cline { 2 - 7 } & $20 \%$ & 186.998 & 361.00 & 803.41 & 430.71 & 308.53 \\
\cline { 2 - 7 } & $30 \%$ & 186.998 & 361.00 & 598.50 & 397.11 & 426.69 \\
\hline \hline
\end{tabular}

c. Slump Test

Data obtained from the execution of slump values on each foundry are showed:

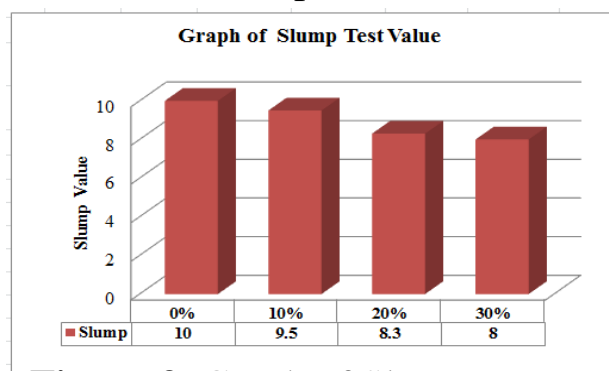

Figure 3. Graph of Slump Test

From the slump test graph above, shows that the slump form will be different according to the aggregate percentage of aggregates artificial. Slump results in $0 \%$ percentage is $10 \mathrm{~cm}$, $10 \%$ percentage is $9.5 \mathrm{~cm}, 20 \%$ percentage is $8.3 \mathrm{~cm}$, and the percentage of $30 \%$ is $8 \mathrm{~cm}$. This shows that the higher percentage of aggregates artificial used, the concrete water absorption will increased.

\section{d. Compressive Strength Test Result}

Testing of concrete compressive strength is completed when the test object is 28 days and 56 days. Prior to the test, the object is removed first from the tank, then stood until the specimen is on the surface dry state, weighing the specimens that after. 
- Tests of concrete compressive strength of 28 days

The results of concrete compressive strength test at age 28 days are showed in table 7 and figure 4 below:

Table 7. Mix Design

\begin{tabular}{|c|c|c|c|c|c|c|c|}
\hline \multirow{3}{*}{$\begin{array}{c}\text { Percentage } \\
\text { of } \\
\text { ALWA }\end{array}$} & \multirow{3}{*}{$\begin{array}{c}\text { Number } \\
\text { of } \\
\text { Specimen }\end{array}$} & \multirow{3}{*}{\begin{tabular}{c|}
$\begin{array}{c}\text { Volume of } \\
\text { Cylinders }\end{array}$ \\
$(\mathrm{cm} 3)$
\end{tabular}} & \multirow{3}{*}{\begin{tabular}{|l|}
$\begin{array}{c}\text { Weight of } \\
\text { Concrete }\end{array}$ \\
$(\mathrm{kg} / \mathrm{m} 3)$ \\
\end{tabular}} & \multirow{3}{*}{$\begin{array}{c}\text { Load } \\
\text { (P) } \\
\text { (KN) }\end{array}$} & \multirow{2}{*}{\multicolumn{2}{|c|}{$\begin{array}{l}\text { Compressive } \\
\text { Strength (MPa) }\end{array}$}} & \multirow{3}{*}{$\begin{array}{c}\text { Classification } \\
\text { SNI } \\
03-6468-2000\end{array}$} \\
\hline & & & & & & & \\
\hline & & & & & $f^{\prime} c$ & $\begin{array}{c}\begin{array}{c}f^{\prime} c \\
\text { (average) }\end{array}\end{array}$ & \\
\hline \multirow{3}{*}{$0 \%$} & BU.1 & 0.0053 & \begin{tabular}{|l|}
2384.26 \\
\end{tabular} & 450 & 25.48 & \multirow{3}{*}{25.67} & \multirow{3}{*}{$\begin{array}{l}\text { Structural } \\
\text { Concrete }\end{array}$} \\
\hline & BU.2 & 0.0053 & \begin{tabular}{|l|}
2493.66 \\
\end{tabular} & 460 & 26.04 & & \\
\hline & BU.3 & 0.0053 & 2461.60 & 450 & 25.48 & & \\
\hline \multirow{3}{*}{$10 \%$} & \begin{tabular}{l|l|} 
BU.A. & \\
\end{tabular} & 0.0053 & \begin{tabular}{|l|l|}
2341.82 \\
\end{tabular} & 410 & 23.21 & \multirow{3}{*}{23.40} & \multirow{3}{*}{$\begin{array}{l}\text { Structural } \\
\text { Concrete }\end{array}$} \\
\hline & \begin{tabular}{|l|} 
BU.A.2 \\
\end{tabular} & 0.0053 & \begin{tabular}{|l|}
2263.54 \\
\end{tabular} & 415 & 23.50 & & \\
\hline & \begin{tabular}{|l|} 
BU.A.3 \\
\end{tabular} & 0.0053 & 2225.81 & 415 & 23.50 & & \\
\hline \multirow{3}{*}{$20 \%$} & \begin{tabular}{|l} 
BU.B.I \\
\end{tabular} & 0.0053 & \begin{tabular}{|l|}
2148.47 \\
\end{tabular} & 315 & 17.83 & \multirow{3}{*}{18.02} & \multirow{3}{*}{$\begin{array}{l}\text { Structural } \\
\text { Concrete }\end{array}$} \\
\hline & \begin{tabular}{|l|} 
BU.B.2 \\
\end{tabular} & 0.0053 & \begin{tabular}{|l|}
2169.22 \\
\end{tabular} & 320 & 18.12 & & \\
\hline & \begin{tabular}{|l|} 
BU.B.3 \\
\end{tabular} & 0.0053 & 2159.79 & 320 & 18.12 & & \\
\hline \multirow{3}{*}{$30 \%$} & BU.C.1 & 0.0053 & 2056.05 & 280 & 15.85 & \multirow{3}{*}{15.29} & \multirow{3}{*}{$\begin{array}{l}\text { Non Structural } \\
\text { Concrete }\end{array}$} \\
\hline & $\begin{array}{l}\text { BU.C. } 2 \\
\end{array}$ & 0.0053 & 2046.61 & 250 & 14.15 & & \\
\hline & BU.C.3 & 0.0053 & \begin{tabular}{|l|}
2091.89 \\
\end{tabular} & 280 & 15.85 & & \\
\hline
\end{tabular}

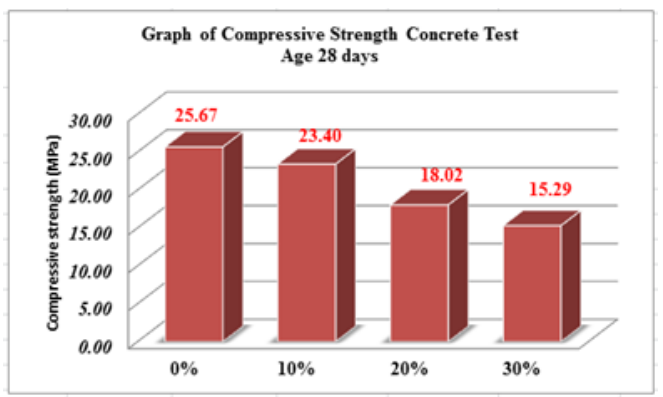

Figure 4. Graph of Compressive Strength Concrete Test Age 28 Day

From Table 7 and Figure 4, showed the compressive strength of concrete reduced when the proportion of aggregates artificial increased. However, the weight of the concrete will be lighter in proportion to the increasing of aggregate artificial. On specimens with $0 \%$ percent aggregate artificial has an average compressive strength of $25.67 \mathrm{MPa}$ and weight of $12.97 \mathrm{~kg}$. While on the specimen with the percentage of $30 \%$ aggregate artificial has an average compressive strength of $15.29 \mathrm{MPa}$ and weight $10.95 \mathrm{~kg}$.

- The strength concrete of 56 days

The concrete compressive strength test results at age 56 days are showed in Table 8.

Table 8. Strength concrete test age 56 days

\begin{tabular}{|c|c|c|c|c|c|c|c|}
\hline \multirow{2}{*}{$\begin{array}{c}\text { Percentage } \\
\text { of ALWA }\end{array}$} & \multirow{2}{*}{$\begin{array}{l}\text { Sample } \\
\text { Test }\end{array}$} & \multirow{2}{*}{$\begin{array}{c}\begin{array}{c}\text { Cylinder } \\
\text { Volume }\end{array} \\
\mathrm{cm}\end{array}$} & \multirow{2}{*}{$\begin{array}{c}\begin{array}{c}\text { Concrete } \\
\text { Weight }\end{array} \\
\mathrm{kg} / \mathrm{m} 3 \\
\end{array}$} & \multirow{2}{*}{$\begin{array}{c}\text { Load (P) } \\
\mathbf{k N}\end{array}$} & \multicolumn{2}{|c|}{$\begin{array}{c}\text { Compressive Strength } \\
\text { (MPa) }\end{array}$} & \multirow{2}{*}{$\begin{array}{l}\text { Classificati } \\
\text { on }\end{array}$} \\
\hline & & & & & $\mathrm{rc}$ & $\begin{array}{c}\mathrm{rc} \\
\text { (Average) }\end{array}$ & \\
\hline \multirow{3}{*}{$0 \%$} & BU. I. 1 & 0.0053 & 2480.46 & 460.00 & 26.04 & \multirow{3}{*}{25.95} & \multirow{3}{*}{$\begin{array}{l}\text { Structural } \\
\text { concrete }\end{array}$} \\
\hline & BU. I. 2 & 0.0053 & 2472.91 & 455.00 & 25.76 & & \\
\hline & BU. I. 3 & 0.0053 & 2429.53 & 460.00 & 26.04 & & \\
\hline \multirow{3}{*}{$10 \%$} & BU. I. A. 1 & 0.0053 & 2271.08 & 420.00 & 23.78 & \multirow{3}{*}{23.87} & \multirow{3}{*}{$\begin{array}{l}\text { Structural } \\
\text { concrete }\end{array}$} \\
\hline & BU. I. A. 2 & 0.0053 & \begin{tabular}{|l|l|}
2301.26 \\
\end{tabular} & 425.00 & 24.06 & & \\
\hline & BU. I. A. 3 & 0.0053 & 2286.17 & 420.00 & 23.78 & & \\
\hline \multirow{3}{*}{$20 \%$} & BU. I. B. 1 & 0.0053 & 2180.54 & 320.00 & 18.12 & \multirow{3}{*}{18.49} & \multirow{3}{*}{$\begin{array}{l}\text { Structural } \\
\text { concrete }\end{array}$} \\
\hline & BU. I. B. 2 & 0.0053 & 2188.09 & 340.00 & 19.25 & & \\
\hline & BU. L. B. 3 & 0.0053 & 2184.31 & 320.00 & 18.12 & & \\
\hline \multirow{3}{*}{$30 \%$} & BU. I. C. 1 & 0.0053 & 2145.64 & 260.00 & 14.72 & \multirow{3}{*}{15.85} & \multirow{3}{*}{\begin{tabular}{|c} 
Non \\
Structural \\
Concrete
\end{tabular}} \\
\hline & BU. I. C. 2 & 0.0053 & \begin{tabular}{|l|l|}
2099.43 \\
\end{tabular} & 300.00 & 16.99 & & \\
\hline & BU. I.C. 3 & 0.0053 & 2074.15 & 280.00 & 15.85 & & \\
\hline
\end{tabular}




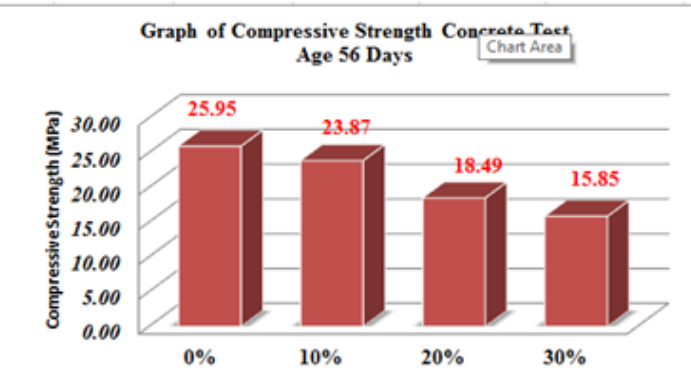

Figure 5. Graph of Compressive Strength Concrete Test Age 56 Days

Based on Table 8 and Figure 5, showed the decreases of concrete compressive strength due to the higher proportion of aggregates artificial. The weight of the concrete will be lighter based on proportion increases of aggregate artificial. On specimens with $0 \%$ percent aggregate artificial has an average compressive strength of $25.95 \mathrm{MPa}$ and average weight of $13.05 \mathrm{~kg}$. While on the specimen with the percentage of $30 \%$ aggregate artificial has average compressive strength of $15.85 \mathrm{MPa}$ and average weight of $11.17 \mathrm{~kg}$.

e. Comparison results of concrete compressive strength

The comparison results of compressive strength of concrete at age 28 days and 56 days are showed in table 9 and figure 6 below.

Table 9. Comparison of compressive strength of 28 day and 56 day.

\begin{tabular}{|c|c|c|c|c|}
\hline \multirow{2}{*}{ Age } & \multicolumn{4}{|c|}{ fc (Mpa) } \\
\cline { 2 - 5 } & $\mathbf{0} \%$ & $\mathbf{1 0} \%$ & $\mathbf{2 0} \%$ & $\mathbf{3 0 \%}$ \\
\hline \multirow{3}{*}{ 28 Days } & 25.48 & 23.21 & 17.83 & 15.85 \\
\cline { 2 - 5 } & 26.04 & 23.50 & 18.12 & 14.15 \\
\cline { 2 - 5 } & 25.48 & 23.50 & 18.12 & 15.85 \\
\hline \multirow{3}{*}{56 Days } & 26.04 & 23.78 & 18.12 & 14.72 \\
\cline { 2 - 5 } & 25.76 & 24.06 & 19.25 & 16.99 \\
\cline { 2 - 5 } & 26.04 & 23.78 & 18.12 & 15.85 \\
\hline
\end{tabular}

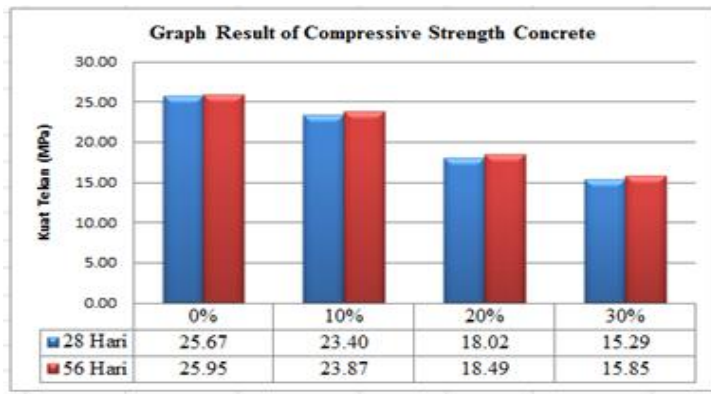

Figure 6. Graph of Compressive Strength Concrete 28 day and 56 day

From the table and figure shows the compressive strength of concrete has increased. However, the increasing in strength is not too large, because the concrete has reached the compressive strength of the plan at the age of 28 days.

f. Relation of volume weight with compressive strength of concrete

The weight of the concrete volume has a great effect on the compressive strength of the concrete, this can be seen in graph 7 below: 


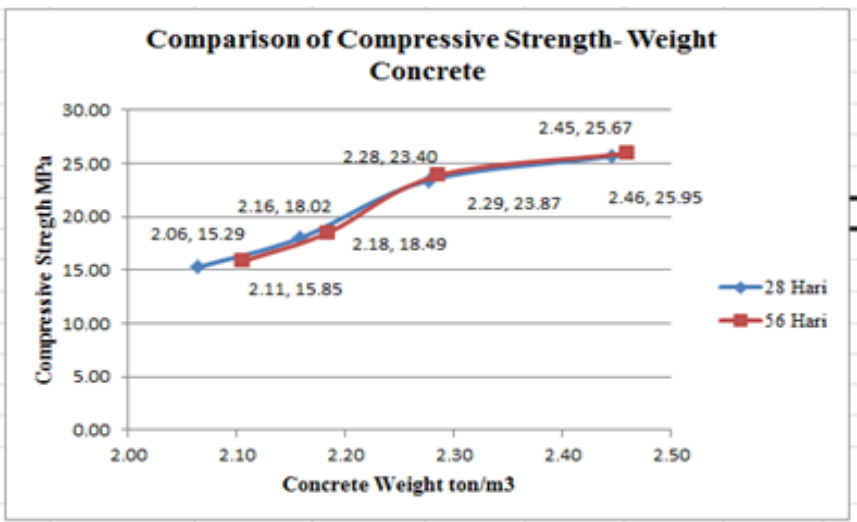

Figure 7. Graph of average compressive strength of concrete aged 28 and 56 Days

Based on Figure 7, weight of the concrete obtained 2.45 ton $/ \mathrm{m} 3$ at 28 days and compressive strength of 25,67 MPa. Concrete weight at age 56 days obtained $2.46 \mathrm{ton} / \mathrm{m} 3 \mathrm{have}$ compressive strength of $25.95 \mathrm{MPa}$. Then on concrete weighing 2.06 ton / m3 at age 28 day have compressive strength $15.29 \mathrm{MPa}$, and weight of concrete at age 56 day with weight 2.11 ton/m3 have compressive strength $15,85 \mathrm{MPa}$. In other words, normal concrete with a large volume weight has a large compressive strength, while the lighter concrete, its compressive strength smaller than normal concrete.

\subsection{Discussion}

The results of the aggregate inspection conducted at the West Aceh Public Works Laboratory indicates that the aggregate used has fulfilled the requirements as concrete-forming materials based on (ASTM C.33-02, 2002), (SNI 03-2461-2002) and (Troxell, 1968) Instead of the absorption of fine aggregate does not meet the criteria implied by (SNI 03-2461-2002) which ranges from $0.4-1.9$. The result of slump test at $0 \%$ percentage was $10 \mathrm{~cm}, 10 \%$ percentage was $9.5 \mathrm{~cm}$, percentage $20 \%$ was $8,3 \mathrm{~cm}$, and percentage $30 \%$ equal to $8 \mathrm{~cm}$. The slump test results showed decreases in slump value. In other words, the higher the percentage of aggregates artificial used the higher the water absorption of concrete. The concrete produced in this study indicates that the concrete is below the normal concrete limit, but not including the lightweight concrete specification. Because based on (Orchard,1979) lightweight concrete has a unit weight of not more than $1900 \mathrm{~kg} / \mathrm{m} 3$. Based on (SNI 03-2461-2002) concrete with 10\% aggregate artificial substitution at 28 and 56 days can be used for structural purposes, since the compressive strength is in the range of 21-40 MPa. Meanwhile, according to (Tjokrodimuljo, 2007) aggregate artificial substitution $20 \%$ - 30\% can still be used for structural purposes, because according to the strength of medium quality concrete press for the use of the structure that is $15-40 \mathrm{MPa}$.

\section{Conclusion}

From the results of research and data procevssing that has been carried out, concrete with artificial lightweight aggregate substitution gives the effect of lightness to the concrete itself. It can be seen on aggregate artificial usage of 10\%, 20\% and 30\% weight average of test specimens continues to decrease. The use of $10 \%$ at age 28 and 56 days, aggregate artficial resulted in the compressive strength of concrete close to the compressive strength of the plan was $23.40 \mathrm{MPa}$ and $23.87 \mathrm{MPa}$, with average weight $12.07 \mathrm{~kg}$ and $12.12 \mathrm{~kg}$. The aggregate usage of aggregates artificial $30 \%$ at age 28 and 56 days of compressive strength of concrete average $15.29 \mathrm{MPa}$ and $15.85 \mathrm{MPa}$ with average weight $10.95 \mathrm{~kg}$ and $11,17 \mathrm{~kg}$, but still can be 
used as structural concrete. Preparation of artificial lightweight aggregate concrete has economic value, because concrete-making materials are obtained easily. However, in the aggregate stages aggregates artificial has several obstacles, due to the equipment used and the process itself is still simple.

\section{References}

ASTM C.33-02. (2002). Standard Spesification for Concrete Aggregates Annual Books of ASTM C.33 - 02a, USA.

ASTM C330-89. (2002). Standard Specification Agregate for Structural Concrete, Annual Books, USA.

Mulyono. (2005). Teknologi Beton, Andi, Yogyakarta.

Orchard, D.F. (1979). Properties and Testing Aggregate, Concrete Technology. Vol. 3, 3rd Edition, Applied Sciences Publisher Ltd., London.

SNI 03-2461-2002, Spesifikasi Agregat Ringan Untuk Beton Ringan Struktural, Badan Standarisasi Nasional, Jakarta.

SNI -03-2847-2002, Persyaratan Beton Struktural Untuk Bangunan Gedung (Beta Version), Badan Standarisasi Nasional, Jakarta.

Tjokrodimuljo, K. (2007). Teknologi Beton, Nafiri. Yogyakarta

Troxell, R.E., et.al. (1968) .Composition And Properties Of Concrete, Mac Graw Hill Book Company. 